\title{
Temperament and character dimensions, marital adjustment, and sexual satisfaction in couples with sexual dysfunction
}

\author{
Cinsel işlev bozukluğu olan çiftlerde mizaç ve karakter boyutları, evlilik \\ uyumu ve cinsel doyum
}

\author{
Cennet Şafak Öztürk', Haluk Arkar² \\ ${ }^{1}$ Assist. Prof. Dr., Adnan Menderes University Faculty of Arts and Sciences, Department of Psychology, Aydin, Turkey \\ 2Prof. Dr., Ege University Faculty of Arts, Department of Psychology, Izmir, Turkey
}

\section{SUMMARY}

Object: The objective of the study is to investigate the differences in temperament and character dimensions, marital adjustment and sexual satisfaction between the couples with and without sexual dysfunction (SD). Methods: The study group consists of 78 married women and 23 married men with SD diagnosis according to DSM-IV-TR diagnostic criteria and also their spouses $(n=202)$. The comparison group is composed of married couples without SD $(n=200)$. The participants were applied Personal Information Form, Temperament and Character Inventory (TCl), Golombok-Rust Inventory of Sexual Satisfaction (GRISS), Dyadic Adjustment Scale (DAS). Results: The couples with SD were observed to have higher cooperativeness and self-transcendence and lower self-directedness scores than those of the comparison group. The women partners in the couples with SD were found to take higher harm avoidance and lower self-directedness scores than the women in comparison group. Dyadic satisfaction, affectional expression and DAS total scores in the couples with SD were seen to be significantly less than those of the couples in the comparison group. It was found out that the women in the couples with SD took significantly higher scores in GRISS total score and all subscales, and men in the couples with SD took significantly higher scores in GRISS total score and subscales of satisfaction, avoidance, premature ejaculation and impotence than those in the comparison group. Discussion: It can be said that cyclothymic character, harm avoidance and self-directedness were the risk factors for SD. Marital adjustment and sexual satisfaction are insufficient in the couples with SD.

Key Words:Sexual dysfunction, personality, marital relationship, sexual satisfaction, couples

\section{ÖZET}

Amaç: Çalışmanın amacı cinsel işlev bozukluğu (CiB) olan ve olmayan çiftler arasındaki mizaç ve karakter boyutları, evlilik uyumu ve cinsel doyumdaki farklılıkları araştırmaktır. Yöntem: Çalışma grubu DSM-IV-TR tanı ölçütlerine göre CiB tanısı alan 78 evli kadın ve 23 evli erkek ile onların eşlerinden $(n=202)$, karşılaştırma grubu CiB olmayan evli çiftlerden $(n=200)$ oluşmuştur. Katılımcılara Kişisel Bilgi Formu, Mizaç ve Karakter Envanteri (MKE), Golombok-Rust Cinsel Doyum Ölçeği (GRCDÖ), Çift Uyum Ölçeği (ÇUÖ) uygulanmıştır. Bulgular: CiB'i olan çiftlerin karşılaştırma grubundan yüksek işbirliği yapma ve kendini aşma, düşük kendini yönetme puanı olduğu görülmüştür. CiB'i olan çiftlerde kadın partnerin karşılaştırma grubundaki kadınlara göre yüksek zarardan kaçınma, düşük kendini yönetme puanı aldıkları bulunmuştur. CiB'i olan çiftlerde çift doyumu, sevgi gösterme ve ÇUÖ toplam puanlarının karşılaştırma grubundaki çiftlere göre anlamlı olarak daha az olduğu görülmüştür. CiB'i olan çiftlerde, kadınların GRCDÖ toplam puanı ve tüm alt ölçeklerinden, erkeklerin GRCDÖ toplam puanı ve doyum, kaçınma, erken boşalma ve empotans alt ölçeklerinden karşılaştırma grubuna göre anlamlı düzeyde daha yüksek puanlar aldıkları bulunmuştur. Sonuç: Siklotimik karakter, zarardan kaçınma ve kendini yönetme özelliklerinin CіB için bir risk faktörü olduğu söylenebilir. CIB olan çiftlerde evlilik uyumu ve cinsel doyum azdır.

Anahtar Sözcükler: Cinsel işlev bozuklukları, kişilik, evlilik ilişkisi, cinsel doyum, çift 


\section{INTRODUCTION}

Sexual dysfunctions (SDs) are a heterogeneous group of disorders that are typically characterized by a clinically significant disturbance in a person's ability to respond sexually or to experience sexual pleasure (1). The Diagnostic and Statistical Manual of Mental Disorders, Fourth Edition-Text Revision (DSM-IV-TR) defines SD as "characterized by disturbance in sexual desire and in the psychophysiological changes that characterize the sexual response cycle and cause marked distress and interpersonal difficulty" (2). SD is a very prevalent disease $(3,4,5,6)$. Its prevalence rate is $43 \%$ for women and $31 \%$ for men (3). SD prevalence in Turkey is found $48.3 \%$ in women and $43.3 \%$ in men $(4,5)$. Sexual function is composed of four mingled phases such as desire, excitement, orgasm and resolution and covers complicated interactions between biological, sociocultural and psychological factors. Healthy functioning of sexual response cycle requires mutual and compatible interaction of several biological (vascular, hormonal, neurological) and psychical factors. The reasons negatively affecting the mentioned biological and psychical systems or complex interaction between them spoil the physiological cycle of sexual responses and cause SD (7). Thus, although it is this much prevalent, the etiology of a sexual problem is not known in many clinical contexts (1). The underlying personal traits can play a role in the development or maintenance of these problems $(8,9)$.

Personality, broadly defined, refers to an individual's characteristic pattern of thinking, feeling and behaving in a variety of contexts across the lifespan (10). There are several models in interpreting the personality (11). Some of these are the Eysenck's personality theory, the Five-Factor Model and the psychobiological model of Cloninger. Eysenck's original research found two main dimensions of temperament: neuroticism and extraversion. Eysenck later added the dimension of psychoticism into the his model. The Five-Factor Model is an adjective-based descriptive model, for characterizing the self or others. According to this model, personality is divided into five broad domains or dimensions. These include extraversion, agreeableness, conscientiousness, emotional stability, and openness to experience (10). A general psychobio- logical model of personality has been developed by Cloninger in order to test the hypothesis about the causal structure of personality (12). This model included four temperament dimensions (novelty seeking, harm avoidance, reward dependence and persistence) which were thought to be genetically separate, moderately stable during life, unchangeable against sociocultural influences and had preconceptual subjectivity in perceptive memory and covered three character dimensions (self-directedness, cooperativeness and self-transcendence) which were presumed to maturate in adulthood and to have influence on individual and social activities by learning introspection about selfness concept. Cloninger's integrative psychobiological approach provides a flexible framework for both clinical assessment and treatment planning (13). In literature, there are contradictory results on whether SD is related to a certain personality dimension or not (14-16). Considering the literature that examines the relationship between sexual functions and personality traits, different results are encountered because of different researching methodologies such as the selection of samples and measurement devices. In a study in which the couples with SD are compared to the control group, sensitivity to rejection and the guilt subtest were found to be important predictors (17). In studies conducted in nonclinical samples, relationships were found between orgasmic difficulties and personality traits such as nervousness, aggressiveness, depressiveness, irritability, sociability, and openness (18), and between dyspareunia and nervousness (16). In studies conducted in clinical sampling with Five-Factor Model, it is found out that a relationship is found in women between sexual problems and higher neuroticism and lower extraversion (19), while neuroticism is the best distinguishing factor between men with and without SD (20). In studies conducted in nonclinical sampling, neuroticism and extraversion were found to be the variables best predicting the attitude to sexuality (14), and the variables of introversion, not being open to new experiences, emotional instability and neuroticism in women, and the variable of neuroticism in men were regarded to be risk factors for developing SD $(21,22)$. These studies showed that sexual arousal and orgasm difficulties in women are strongly related to higher neuroticism and lower extraversion and orgasmic infrequency is strongly 
related to introversion, emotional instability and not being open to new experiences. Neuroticism in SD was seen to be in a central role in men. Depending on the Cloninger's model, a few number of studies are observed to have been conducted on SD and different results are observed to have been obtained from these studies. In a study conducted with vaginismus patients, a significant difference was not found out between vaginismus group and control group except the emotionality item scores of reward dependence subscale. In this sampling, any character trait specific to vaginismus has not been found out (15). In another study, the participants with generalized and lifelong premature ejaculation were seen to get higher scores of harm avoidance (23).

Marital adjustment is the individual's perception of degree to meet the requirements in his/her marriage relationship (24). This means the general satisfaction gotten from marriage as well as more specific conditions such as the satisfaction gotten from the friendship and sexuality in marriage. It is stated that the success of a marriage is largely dependent on the sexual relationship between the couple (25). Marriage relationship plays an important role both as the reason and as the result of SD (26). It is mentioned that SD has an effect on the well-being of couples' marriages (27). The conducted studies have shown that the couples with SD have reduced satisfaction with the marriage relationship (28-30). In some studies, any relationship was not found between SD and marital adjustment (31).

Sexual satisfaction is an important component of human sexuality (32). Sexual satisfaction is composed of affective/emotional components as well as physical components. Physical sexual satisfaction refers to satisfaction or "pleasurableness of sexual intercourse," whereas emotional sexual satisfaction relates to "happiness of steady relationships" (33). The physical components of sexual satisfaction are the factors such as the frequency of sexual intercourse, the amount of sexual desire, the duration of foreplay, the duration of sexual intercourse (penis penetration), getting satisfaction from the variety of sexual activities, the sexual arousal, negative emotional reactions against sexuality, orgasmic consistency, SD, awareness of physical reactions. It is reported that $\mathrm{SD}$ and sexual satisfaction are interrelated (32). The people with more sexual problems tend to report lower sexual satisfaction than those with fewer problems (34). Sexual satisfaction have attracted very little attention in empirical or clinical literature.

As it will be understood from all of these mentioned, the relationship between SD and personality, marital adjustment and sexual satisfaction keep being discussed in the literature. It is seen in the literature that there are not enough studies that deal with SDs in couples. Whereas, sexuality is a phenomenon experienced between two people and any sexual problem that happen in one of the spouses affects the sexual life of the other spouse $(35,25)$. Also, it is seen that there are inadequate number of studies that compares the mentioned variables in couples with $\mathrm{SD}$ to a comparison group.

The first objective in this study is to research whether the temperament and character traits differ or not in couples with and without SD, depending on psychobiological model of Cloninger. The second objective is to compare the couples with SD with nonclinical comparison group in terms of the marital adjustment and sexual satisfaction. The outcomes to be obtained are expected to add new information to the knowledge of complex factors causing SD and thus to contribute to the field by allowing better treatment options to be developed.

\section{METHOD}

\section{Participants}

The sample of the study is composed of 201 married couples $(\mathrm{n}=402)$ at $18-55$ age. The study group consists of 78 married women and 23 married men $(n=101)$ and their spouses $(n=101)$, who applied to gynecology and urology outpatient clinics of Izmir Ege Maternity Hospital and Gynecological Diseases Training and Research Hospital for a sexual problem, whose treatments were not started yet and who were diagnosed with SD according to DSM-IV-TR diagnostic criteria (2) and who volunteered to participate in the study. Male and female partners of patients who were 
Temperament and character dimensions, marital adjustment, and sexual satisfaction in couples with sexual dysfunction

diagnosed as having a sexual dysfunction had significant abnormal scores in several sexual dimensions when compared with normal volunteers (36). For this reason, the diagnosed individual and his/her spouse formed the study group. SD was diagnosed by the psychiatrist according to DSMIV-TR diagnostic criteria. Those who were illiterate, who had mental retardation, and who had any physical and psychological/psychiatric disorder were excluded from the study. Scales were given to a total of 110 couples $(n=220)$ and 9 couples $(n=$ 18) were left out of the study because of insufficient data. Finally, 101 couples $(n=202)$ were included in the study. The mean age of the study group was 31.69 ( $\mathrm{SD}=8.19$, age range: $18-55$ years). $50 \%$ of the participants in the study group were primary school graduates and great majority of them were of urban origin (62.9\% large city and $22.3 \%$ city). $43.6 \%$ of the participants in this group consisted of workers, while $70.8 \%$ of them were at the level of middle income. The comparison group was chosen according to accessibility and availability principle. The comparison group was composed of 100 nonclinical married couples living in houses located in the streets incidentally chosen by going to various districts of Izmir, who did not have any sexual problem and who volunteered to participate in the study. Those who were illiterate and who had any physical and psychological/psychiatric disorder were excluded from the study. Scales were given to a total of 350 married couples $(n=700)$ and 210 married couples $(n=420)$ have not returned the scales. Forty married couples $(n=80)$ were left out of the study because of insufficient data or for not meeting the study standards. Finally, 100 couples ( $\mathrm{n}=200)$ were included in the study. The comparison group has similar sociodemographic characteristics with the study group. The mean age of the comparison group was 35.69 (SD $=6.67$, age range: $18-55$ years). $43.5 \%$ of the comparison group were primary school graduates and great majority of them were of urban origin $(56.5 \%$ large city and $24.5 \%$ city). $41 \%$ of the participants in this group consisted of workers and $66.5 \%$ of them were at the level of middle income.

Considering the SD diagnoses that the women and men in the study group received, it is seen that in women, 22 people were diagnosed with "hypoactive sexual desire disorder", 1 person with "sexual aver- sion disorder", 7 people with "female orgasmic disorder", 15 people with "dyspareunia" and 33 people with "vaginismus"; in men 1 person was diagnosed with "hypoactive sexual desire disorder", 5 people with "male erectile disorder" and 17 people with "premature ejaculation".

\section{Data Collecting Tools}

Personal Information Form: This is a form prepared to determine the demographic variables such as gender, age, education level, income level, settlement place, occupational status. In the form there were also two questions as to detecting whether the participants had ever applied to a psychologist or psychiatrist and whether they had a chronic/ongoing medical disease.

Temperament and Character Inventory (TCI): TCI is a self-report scale that consists of 240 items filled in as true/false and that can be applied to people over the age of 17. Depending on Cloninger's (12) psychobiological personality theory, it measures four temperament (novelty seeking, harm avoidance, reward dependence and persistence) and three character (self-directedness, cooperativeness and self-transcendence) dimensions. Köse et al. (37) performed only the validity and reliability study of the inventory in healthy individuals, and Cronbach alpha coefficients were found between 0.60-0.85 in temperament dimensions and 0.82-0.83 in character dimensions. Arkar et al. (38) conducted the validity and reliability study in the group consisting of both healthy and psychiatric individuals. Cronbach alpha coefficients ranged from 0.55 to 0.84 for temperament dimensions and 0.80 to 0.84 for character dimensions. Psychometric studies show that the scale is valid in Turkey $(37,38)$.

Dyadic Adjustment Scale (DAS): It is a self-report scale that is used to evaluate the nature of couples' marriages, couples' adjustment and the quality of adjustment and that was developed by Spainer (39). DAS is a 5, 6 or 7-point Likert-type scale of 32 items that is composed of four subscales (dyadic satisfaction, dyadic consensus, dyadic cohesion and affectional expression) that have scores ranging between 0 and 151. Besides, two items were arranged as yes/no questions. A total of five scores 
is obtained from the scale, four of which are from the four subscales and one is from the sum of them. High scores are regarded as high marital adjustment. The validity and reliability study of the scale in Turkish sample was performed by Fişıloğlu and Demir (40). The Cronbach alpha coefficients of the scale was 0.92 and the reliability coefficient was 0.86 . The Cronbach alpha coefficients obtained from the subscales ranged from 0.75 to 0.83 .

Golombok-Rust Inventory of Sexual Satisfaction (GRISS): GRISS is a measuring tool for assessing the nature of sexual relations and SDs. The scale has two forms prepared for women and men each consisting of 28 items answered in 5-point Likerttype. In forms of women and men there are 7 subscales, five of which are common (frequency, communication, satisfaction, avoidance and sensuality). In form for women, there are different subscales as vaginismus and orgasm disorder (anorgasmia) and in form for men there are different subscales as premature ejaculation, and impotence (erectile dysfunction). In the assessment of the scale, both the total score of the scale and the scores obtained from subscales can be used. The raw scores can be transformed into standard scores ranging from 1 to 9. High scores indicate deterioration in the quality of sexual life and in sexual functioning. Standard scores above 5 can be considered an indicator of dysfunction. Turkish adaptation of the inventory developed by Rust and Golombok (41) was made by Tuğrul et al. (42), and evidence for its validity and reliability has been obtained. Tuğrul et al. (42) found the Cronbach alpha coefficient as 0.91 for females and 0.92 for males in terms of total score. The Cronbach alpha coefficients obtained from the subscales ranged from 0.51 to 0.88 in female form and 0.63 to 0.91 in male form.

\section{Procedure}

The diagnosis of the couples in the study group was made by a psychiatrist. The persons applying as outpatients to gynecology and urology polyclinics due to a sexual problem were later on directed to a psychiatrist for SD diagnosis, and the evaluation and diagnosis procedures were performed by psychiatrist. The participants having volunteered to take part in the study with their spouses were given informed consent form, then spouses were enabled to fill in the scales given in large envelopes separately. The participants of the study group filled in the scales in a safe, quiet and special room of hospital. The participants of comparison group who were chosen according to accessibility and availability principle having volunteered to participate in the study with their spouses were given informed consent form and were asked to fill in the scales given in large envelopes separately. Participants put the scales which they filled into the envelope, closing the envelope and submitting it to the researcher. In order to eliminate a probable rank effect, the order of scales were systematically changed, keeping the Personal Information Form at the top. The needed instructions were given at the beginning of the scales. The ethical approval of the study was taken from Clinical Studies Ethical Committee of Ege University.

\section{Statistical Analysis}

The data were analyzed with SPSS (Statistical Package for the Social Sciences) 16 package program. Prior to statistical analyses, all of the variables were examined through various SPSS programs for accuracy of data entry, missing values, and suitability between their distributions and assumptions of multivariate analysis. There was no outlier between cases according to Mahalanobis distance criterion $(\mathrm{p}<0.001)$. Normality and linearity was checked and found to be satisfactory. Different groups of diagnosis have been combined under a single sampling group to attain a sampling size necessary for statistical analysis. Multivariate analysis of variance (MANOVA) was performed in examining whether group, age and education have effects on the dimensions of GRISS and it was performed in testing the differences between the study and comparison group. The results were assessed at the significance level of $p<0.05$.

We conducted a post hoc power analysis with the program GPower to find out whether our study had enough statistical power (43). The sample size of 402 was used for the statistical power analyses. To perform post hoc power analysis for each statistical analysis, the standard effect sizes of Cohen were used (44). The alpha level used for this analyses 
Temperament and character dimensions, marital adjustment, and sexual satisfaction in couples with sexual dysfunction

was set at 0.05 . The post hoc analyses revealed that the statistical power for this study was determined to be ranged from 0.96 to 0.99 for the detection of a medium effect size $\left(\mathrm{f}^{2}=0.0625\right)$. Thus, in this study there was adequate power (i.e., power $\geq .80$ ) at the medium effect size level.

\section{RESULTS}

\section{The analysis of sociodemographic variables}

The sample of the study is divided into three groups in terms of age variable (18-28, 29-39, 40-55 age) and level of education (primary school, high school, university). A 2 (group) by 3 (age) by 3 (education) factor multivariate analysis of variance (MANOVA) was applied for women and men separately so as to examine the effects of variables of group (study group vs. comparison group), age and education on the scores gotten from GRISS. The total score of GRISS with its sub-dimensions was accepted as dependent variable. The performed analysis showed that there was a significant "group" main effect both in women $(\mathrm{F}(1,183)=50.58$, $\mathrm{p}<.01)$ and in men $\mathrm{F}(1,183)=23.46, \mathrm{p}<.01)$. It was found out that the mean total GRISS scores of women and men in the study group $(\mathrm{M}=46.53, \mathrm{SD}$ $=15.60 ; \mathrm{M}=26.15, \mathrm{SD}=11.48$ respectively) were significantly higher than the mean total GRISS scores of women and men in the comparison group $(\mathrm{M}=28.84, \mathrm{SD}=11.36 ; \mathrm{M}=19.26, \mathrm{SD}=7.88$ respectively). Yet, it was observed that in both women and men, age and education main effect and group by age, group by education, age by education and group by age by education interaction effect do not have significant impact on the dimensions of GRISS. Determination of main effect "group" ensured trying to evaluate that these groups are comparable groups (study group vs. comparison group) to one another for other analyses of the study.

Comparison of study and comparison groups in
terms of scale scores from Temperament and
Character Inventory and Dyadic Adjustment Scale

The mean scores and standard deviations of TCI and DAS scales according to group (study group vs. comparison group) and gender are given in Table 1 .
So as to assess potential group and gender differences regarding TCI and DAS, 2 (study group vs. comparison group) X 2 (women vs. men) multivariate analysis of variance (MANOVA) was performed. In the analysis TCI has seven dimensions as novelty seeking, harm avoidance, reward dependence, persistence, self-directedness, cooperativeness, and self-transcendence, and DAS has four sub-dimensions as dyadic satisfaction, dyadic consensus, dyadic cohesion and affectional expression, and DAS total score is accepted as dependent variable.

In dependent variable of the harm avoidance scale, two-way analysis of variance revealed significant group by gender interaction (Table 2). Women included in the study group $(\mathrm{M}=20.17, \mathrm{SD}=5.63)$ had significantly higher scores on harm avoidance than women in comparison group $(\mathrm{M}=18.58$, SD =5.61), (p.015).

In dependent variable of self-directedness, two-way analysis of variance showed significant main effect for group and a significant group by gender interaction (Table 2). Those included in the study group $(\mathrm{M}=26.35, \mathrm{SD}=6.41)$ had significantly lower scores on self-directedness than those in the comparison group $(\mathrm{M}=28.00, \mathrm{SD}=6.59),(\mathrm{p}=.010)$. In terms of interaction effect, self-directedness scores of the women in the study group $(\mathrm{M}=24.54, \mathrm{SD}=5.36)$ were lesser than that of the women in the comparison group $(\mathrm{M}=27.69, \mathrm{SD}=6.76),(\mathrm{p}=.019)$.

Significant main effect of group was obtained with two-way analysis of variance in the dependent variables of cooperativeness and self-transcendence (Table 2). It was found that those in the study group $(\mathrm{M}=28.60, \mathrm{SD}=4.63 ; \mathrm{M}=20.31, \mathrm{SD}=5.28$, respectively) had significantly higher scores on cooperativeness and self-transcendence than the ones in the comparison group $(\mathrm{M}=27.45, \mathrm{SD}=5.15 ; \mathrm{M}=$ $19.01, \mathrm{SD}=5.33$ respectively $),(\mathrm{p}<.05)$.

In the dependent variables of dyadic satisfaction, affectional expression, and DAS total score, twoway analysis of variance showed significant main effect for group (Table 2). It was found out that the mean of subscale scores of dyadic satisfaction, affectional expression and mean total scores of 
Table 1. Means and standard deviations of TCI and DAS according to group and gender

\begin{tabular}{|c|c|c|c|c|c|c|c|c|c|c|c|c|}
\hline & \multicolumn{6}{|c|}{$\begin{array}{l}\text { Study Group } \\
\quad(\mathrm{n}=202)\end{array}$} & \multicolumn{6}{|c|}{$\begin{array}{c}\text { Comparison Group } \\
(\mathrm{n}=200)\end{array}$} \\
\hline & \multicolumn{2}{|c|}{$\begin{array}{l}\text { Women } \\
(\mathrm{n}=101)\end{array}$} & \multicolumn{2}{|c|}{$\begin{array}{c}\text { Men } \\
(n=101)\end{array}$} & \multicolumn{2}{|c|}{$\begin{array}{c}\text { Total } \\
(\mathrm{n}=202)\end{array}$} & \multicolumn{2}{|c|}{$\begin{array}{l}\text { Women } \\
(\mathrm{n}=100)\end{array}$} & \multicolumn{2}{|c|}{$\begin{array}{c}\text { Men } \\
(\mathrm{n}=100)\end{array}$} & \multicolumn{2}{|c|}{$\begin{array}{c}\text { Total } \\
(n=200)\end{array}$} \\
\hline Dimensions & $\mathrm{M}$ & $\mathrm{SD}$ & $\mathrm{M}$ & $\mathrm{SD}$ & $\mathrm{M}$ & $\mathrm{SD}$ & $\mathrm{M}$ & $\mathrm{SD}$ & $\mathrm{M}$ & $\mathrm{SD}$ & M & $\mathrm{SD}$ \\
\hline TCI & & & & & & & & & & & & \\
\hline $\begin{array}{l}\text { Novelty } \\
\text { Seeking }\end{array}$ & 16.86 & 4.07 & 17.17 & 4.61 & 17.01 & 4.34 & 16.19 & 4.15 & 16.85 & 4.77 & 16.52 & 4.47 \\
\hline $\begin{array}{l}\text { Harm } \\
\text { Avoidance }\end{array}$ & 20.17 & 5.63 & 15.46 & 5.27 & 17.82 & 5.93 & 18.58 & 5.61 & 16.55 & 5.42 & 17.56 & 5.60 \\
\hline $\begin{array}{l}\text { Reward } \\
\text { Dependency }\end{array}$ & 14.27 & 2.96 & 13.39 & 3.02 & 13.83 & 3.01 & 14.44 & 3.21 & 12.80 & 3.03 & 13.62 & 3.22 \\
\hline Persistence & 5.21 & 1.57 & 5.71 & 1.62 & 5.46 & 1.61 & 5.53 & 1.68 & 5.45 & 1.83 & 5.49 & 1.75 \\
\hline $\begin{array}{l}\text { Self- } \\
\text { Directedness }\end{array}$ & 24.54 & 5.36 & 28.16 & 6.86 & 26.35 & 6.41 & 27.69 & 6.76 & 28.31 & 6.43 & 28.00 & 6.59 \\
\hline Cooperativeness & 28.22 & 4.44 & 28.99 & 4.80 & 28.60 & 4.63 & 27.98 & 4.80 & 26.93 & 5.45 & 27.45 & 5.15 \\
\hline $\begin{array}{l}\text { Self- } \\
\text { Transcendence }\end{array}$ & 21.28 & 4.88 & 19.33 & 5.51 & 20.31 & 5.28 & 19.50 & 5.26 & 18.53 & 5.38 & 19.01 & 5.33 \\
\hline DAS & & & & & & & & & & & & \\
\hline $\begin{array}{l}\text { Dyadic } \\
\text { Satisfaction }\end{array}$ & 35.55 & 7.41 & 38.73 & 6.16 & 37.14 & 6.98 & 39.52 & 6.09 & 41.68 & 4.27 & 40.60 & 5.36 \\
\hline $\begin{array}{l}\text { Dyadic } \\
\text { Consensus }\end{array}$ & 49.27 & 9.55 & 50.86 & 9.16 & 50.06 & 9.37 & 50.95 & 9.15 & 52.15 & 8.55 & 51.55 & 8.85 \\
\hline $\begin{array}{l}\text { Dyadic } \\
\text { Cohesion }\end{array}$ & 14.17 & 5.11 & 15.35 & 5.10 & 14.76 & 5.13 & 15.27 & 4.26 & 16.03 & 4.14 & 15.65 & 4.21 \\
\hline $\begin{array}{l}\text { Affectional } \\
\text { Expression }\end{array}$ & 7.44 & 2.48 & 8.65 & 2.35 & 8.04 & 2.48 & 9.30 & 2.19 & 9.94 & 1.74 & 9.62 & 2.00 \\
\hline Total Score & 106.4 & 19.7 & 113.6 & 17.90 & 110.0 & 19.12 & 115.0 & 18.11 & 119.8 & 14.20 & 117.4 & 16.41 \\
\hline
\end{tabular}

TCI: Temperament and Character Inventory; DAS: Dyadic Adjustment Scale

DAS were significantly lower in those in the study group $(\mathrm{M}=37.14, \mathrm{SD}=6.98 ; \mathrm{M}=8.04, \mathrm{SD}=2.48 ; \mathrm{M}$ $=110.03, \mathrm{SD}=19.12$, respectively) than those in the comparison group $(\mathrm{M}=40.60, \mathrm{SD}=5.36 ; \mathrm{M}=9.62$, $\mathrm{SD}=2.00 ; \mathrm{M}=117.42, \mathrm{SD}=16.41$ respectively), $(\mathrm{p}<.001)$.

Comparison of study and comparison groups in terms of Golombok-Rust Inventory of Sexual Satisfaction
One-way multivariate analysis of variance (MANOVA) was carried out to assess the relationships between the group (study group vs. comparison group) and GRISS dimensions. In the analysis seven dimensions of GRISS and its total score were accepted as dependent variable for women and men separately. The obtained results are seen in the Table 3.

The analysis carried out through the use of wilks 
Temperament and character dimensions, marital adjustment, and sexual satisfaction in couples with sexual dysfunction

Table 2. TCI and DAS significant MANOVA results

\begin{tabular}{|c|c|c|c|c|c|}
\hline Source & Factor & $\mathrm{F}$ & $\mathrm{df}$ & $\mathrm{p}$ & $\overline{\text { Partial }} \eta^{2}$ \\
\hline \multicolumn{6}{|c|}{ Temperament and Character Inventory } \\
\hline Harm Avoidance & Group*Gender & 5.99 & 1 & $.015^{*}$ & .01 \\
\hline \multirow[t]{2}{*}{ Self-Directedness } & Group & 6.65 & 1 & $.010 *$ & .01 \\
\hline & Group*Gender & 5.56 & 1 & $.019 *$ & .01 \\
\hline Cooperativeness & Group & 5.59 & 1 & $.018 *$ & .01 \\
\hline Self-Transcendence & Group & 6.09 & 1 & $.014 *$ & .01 \\
\hline \multicolumn{6}{|l|}{ Dyadic Adjustment Scale } \\
\hline Dyadic Satisfaction & Group & 32.33 & 1 & $.000 * * *$ & .07 \\
\hline Affectional Expression & Group & 50.57 & 1 & $.000 * * *$ & .11 \\
\hline DAS Total Score & Group & 17.70 & 1 & $.000 * * *$ & .04 \\
\hline
\end{tabular}

${ }^{*} \mathrm{p}<.05, * * * \mathrm{p}<.001$

TCI: Temperament and Character Inventory; DAS: Dyadic Adjustment Scale

criteria for women in study group and comparison group showed that there was significant main effect for group (Wilks $\lambda=57, \mathrm{~F}(8,192)=17.53, \mathrm{p}<.001$ ). Multi variable $\eta^{2}$ based on Wilks Lambda value of 0.42 was strong enough. The women in the study group got significantly higher mean scores from GRISS total score and all sub-dimensions than the women in the comparison group $(\mathrm{p}<.05)$, (Table 3$)$.

The analysis performed by using wilks criteria for men in the study and comparison group showed that there was significant main effect for group (Wilks $\lambda=81, \mathrm{~F}(8,192)=5.44, \mathrm{p}<.001$ ). Multi variable $\eta^{2}$ based on Wilks Lambda value of 0.18 was strong enough. As seen in the Table 3, the men in the study group got significantly higher mean scores from GRISS total score and satisfaction, avoidance, premature ejaculation and impotence sub-dimensions than those in the comparison group $(\mathrm{p}<.05)$. In dependent variables of frequency, communication and sensuality, significant differences were not found between study and comparison groups with one-way analysis of variance.

\section{DISCUSSION}

This study aims to examine the personality traits, marital adjustments and sexual satisfactions of couples with and without SD. The results indicated significant differences in temperament and character dimensions between the study and comparison groups. The first finding is that the couples with SD have higher cooperativeness and self-transcendence character traits and lower self-directedness character trait than the comparison group. The people with higher cooperativeness and self-trans- cendence character traits and lower self-directedness character trait are socially tolerant, empathetic, helpful, compassionate, self-forgetful and spiritual accepting but have lower self-esteem and troubles in inner organization (12). This corresponds to cyclothymic character in the triple interactions (character cube) of character traits in TCI (45). In people with cyclothymic character, there is susceptibility to rejection (lower self-directedness, higher cooperativeness) dependent on atypical depressive symptoms with oscillating vanity and shame. However, their higher self-transcendence is associated with their being more suggestible, so that they are insecurely joyful and have more frequent mood swings (45). Any findings were not encountered in literature about the relationship between SD and cyclothymic character type. This situation can be caused by both the differences of measuring tools used and very few studies made with TCI. Therefore, further studies and repetition of findings are needed to understand this relationship. Still, this finding that we found out made us think that cyclothymic character type can be a risk factor for SD. The second finding is that the women in the study group exhibited higher harm avoidance temperament trait and lower self-directedness character trait than women in the comparison group. Harm avoidance can be regarded as a heritable bias in the inhibition or cessation of behaviors, such as pessimistic worry in anticipation of future problems, passive avoidant behaviors such as fear of uncertainty and shyness of strangers, and rapid fatigability (38). The people with low selfdirectedness have low self-esteem, blame others for their problems, feel uncertain of their identity or purpose and are often reactive, dependent, and resourceless (12). It can be said that in couples 
Table 3. Comparison of study and comparison groups in terms of GRISS scale scores for women and men

\begin{tabular}{|c|c|c|c|c|c|c|c|c|}
\hline \multirow[b]{2}{*}{ Women } & \multicolumn{2}{|c|}{$\begin{array}{c}\text { Study } \\
\text { Group } \\
(\mathrm{n}=101)\end{array}$} & \multicolumn{2}{|c|}{$\begin{array}{c}\text { Comparison } \\
\text { Group } \\
(\mathrm{n}=100)\end{array}$} & \multirow[b]{2}{*}{$\mathrm{F}$} & \multirow[b]{2}{*}{$\mathrm{df}$} & \multirow[b]{2}{*}{$\mathrm{p}$} & \multirow[b]{2}{*}{ Partial $\eta^{2}$} \\
\hline & $\mathrm{M}$ & $\mathrm{SD}$ & $\mathrm{M}$ & $\mathrm{SD}$ & & & & \\
\hline GRISS Total Score & 46.53 & 15.60 & 28.84 & 11.36 & 84.26 & 1 & $.000 * * *$ & .29 \\
\hline Frequency & 4.10 & 2.13 & 3.22 & 1.70 & 10.57 & 1 & $.001 * *$ & .05 \\
\hline Communication & 3.55 & 2.26 & 2.89 & 1.95 & 4.93 & 1 & $.027 *$ & .02 \\
\hline Satisfaction & 6.77 & 3.83 & 3.38 & 2.91 & 49.78 & 1 & $.000 * * *$ & .20 \\
\hline Avoidance & 4.72 & 3.80 & 2.78 & 2.17 & 19.72 & 1 & $.000 * * *$ & .09 \\
\hline Sensuality & 4.14 & 3.82 & 2.74 & 2.35 & 9.85 & 1 & $.002 * *$ & .04 \\
\hline Vaginismus & 9.24 & 4.65 & 5.00 & 2.55 & 64.27 & 1 & $.000 * * *$ & .24 \\
\hline \multirow[t]{2}{*}{ Anorgasmia } & 7.58 & 3.71 & 4.84 & 2.74 & 35.48 & 1 & $.000 * * *$ & .15 \\
\hline & \multicolumn{2}{|c|}{$\begin{array}{c}\text { Study } \\
\text { Group } \\
(\mathrm{n}=101) \\
\end{array}$} & \multicolumn{2}{|c|}{$\begin{array}{c}\text { Comparison } \\
\text { Group } \\
(\mathrm{n}=100) \\
\end{array}$} & & & & \\
\hline Men & $\mathrm{M}$ & $\mathrm{SD}$ & $\mathrm{M}$ & $\mathrm{SD}$ & $\mathrm{F}$ & df & $\mathrm{p}$ & Partial $\eta^{2}$ \\
\hline GRISS Total Score & 26.15 & 11.48 & 19.26 & 7.88 & 24.60 & 1 & $.000 * * *$ & .11 \\
\hline Frequency & 3.08 & 1.94 & 2.69 & 1.66 & 2.44 & 1 & .120 & \\
\hline Communication & 2.10 & 2.03 & 2.10 & 1.74 & .00 & 1 & .974 & \\
\hline Satisfaction & 5.68 & 3.25 & 3.31 & 2.42 & 34.31 & 1 & $.000 * * *$ & .14 \\
\hline Avoidance & 1.76 & 2.12 & .92 & 1.10 & 12.41 & 1 & $.001 * *$ & .05 \\
\hline Sensuality & 1.31 & 1.85 & 1.00 & 1.47 & 1.78 & 1 & .183 & \\
\hline $\begin{array}{l}\text { Premature } \\
\text { Ejeculation }\end{array}$ & 6.09 & 3.59 & 4.79 & 2.85 & 8.17 & 1 & $.005 * *$ & .03 \\
\hline Impotence & 3.19 & 2.81 & 2.37 & 1.88 & 5.98 & 1 & $.015 *$ & .02 \\
\hline
\end{tabular}

GRISS: Golombok -Rust Inventory of Sexual Satisfaction

with $\mathrm{SD}$, women partners have significantly higher cautious, shyness, skepticism, and pessimism, but lower responsibility, purposefulness, skillfulness, and self-esteem. In literature, certain personality traits in women are seen as risk factors to develop SD $(21,46)$. Different results are encountered in very few studies made with TCI. In a study, the women with "vestibulodynia" (former vulvar vestibulitis sendrome) took higher scores from harm avoidance temperament traits and lower scores from self-directedness character traits (47). In other studies, the women with dyspareunia got higher scores from harm avoidance, reward dependence and self-directedness than the control group (48-51). In women with lifelong vaginismus, higher harm avoidance trait was found than the healthy women without sexual complaints (52). Borg et al. (52) stated that harm avoidance trait can have a direct effect in the development and maintenance of vaginismus. The findings that we obtained from 
Temperament and character dimensions, marital adjustment, and sexual satisfaction in couples with sexual dysfunction

our study made us think that high in harm avoidance temperament trait and low in self-directedness character trait can be a risk factor in the development and maintenance of SD for women. In literature it is stated that personality traits can cause SD (18,53). Barnes and Malamuth (54) said that personality traits seem to predict individual differences in sexual arousal and behavioral patterns. Personality traits that we obtained in our study can be biased traits of individuals having sexual functions at a lower level. These traits can play a role in the development and maintenance of SD by causing deterioration in the sexual response cycle of sexual function.

In our study, any personality pattern specific to male partner was not seen in couples with SD. A possible explanation for us to obtain such a finding may be related to the utilized measuring device. There are several limitations in the nature of the personality measuring devices. In literature, it is observed that there are different results in two studies that use The NEO Five-Factor Inventory (NEO-FFI) and The revised NEO Personality Inventory (NEO PIR) $(19,20)$. In the first study, it is found out that men with SD presented significantly higher levels of neuroticism when compared to sexually healthy men. In the other study, it was seen that there was no relationship between SD and personality measures in men. Only one study is encountered in the literature, in which Temperament and Character Inventory-Revised (TCI-R) is used (23). In this study, any important difference is not noticed in TCI-R scores of participants with premature ejaculation in comparison to general population. In the literature, the studies conducted on personality traits of men with SD are observed not to give consistent results. Depending on these studies and the result obtained from our research, we can say that the nature of the relationship between male SD and personality traits cannot be still defined very well. For this reason, it is necessary to make longitudinal studies with a large sample for making further comments.

In our study, marital adjustment and sexual satisfaction were found to be less in the couples with SD than those in the comparison group. Spanier (39) defined marital adjustment as a process, the outcome of which is determined by the degree of (a) troublesome dyadic differences; (b) interpersonal tensions and personal anxiety; (c) dyadic satisfaction; (d) dyadic cohesion; and (e) consensus on matters of importance to dyadic functioning. The sum of four subscales in DAS provides a total index meaning marital adjustment. Dyadic satisfaction assesses the perception of happiness or unhappiness in a couple's relationship such as the frequency of quarrels, the pleasure of spending time together, dyadic consensus assesses the level of agreement and disagreement between partners on topics such as free time management and finances or religion, friendships, and home organisation, dyadic cohesion assesses the amount of time spent by the partners on mutually enjoyable activities such as social interests, dialogue or having common goals, affectional expression assesses how the couples express their inner feelings, loves and sexuality (55). In our study, it was seen that marital adjustments of the couples with SD were significantly lower than the couples in the comparison group. In a study in which marital adjustments of couples with or without hypoactive sexual desire were assessed, significant differences were found in marital adjustments of two groups (28). In another study, it was concluded that marital adjustments of couples with low sexual desire were more insufficient than the couples without low sexual desire (29). In a study conducted with 20 women with SD and their spouses and control group of 23 couples, women with SD made more negative evaluations than the control group as regards their marriage expectations, quality of spouse's relationships and activities done with spouse alone more negatively. In this study it was concluded that female SD and marriage life interact between each other (30). In a review, it was stated that the studies show that marriage dynamics are often dysfunctional in men with erectile disorder (56). The findings of all of these studies suggest that there is a significant relationship between sexual function and relationship function. The result we obtained in our study supports these findings.

In our study, it was noticed that the couples with SD have significantly lower scores of dyadic satisfaction and affectional expression subscales than the couples in the comparison group. The dyadic satisfaction subscale is composed of the individual's perception of issues regarding the discussion of 
divorce, leaving the house after a fight, quarreling, degree of happiness. In this study, this lower amount of dyadic satisfaction in the the couples with SD, when compared with the comparison group, may reflect unhappiness in their relationship, the frequency of their quarrels and their thoughts of separation or divorce. In a study, 50 couples in search for divorce were compared to control group of 30 well adjusted couples. Sex related factors and SD were found to be related to the divorce seeking behaviour (57). In a study conducted with males applied to SD clinic as outpatients, the conflict prevalence within the family and within the couple was observed to be high among these patients. As reported by patients, female sexual function parameters continued their significant association with conflict types (58). The presence of unsolved conflicts in couples' relationships has long been thought to cause or maintain SD as well as influence the outcome of therapeutic intervention for sexual problems (53). Affectional expression is related to the sign of emotion and sexual relation. That two out of four items composing this subscale are related to disagreement on sexual relation may have enabled us to obtain this result in our study. Sexuality is an important part of marriage. When a problem occurs in sexual functions, this can be quite stressful for both spouses and removes the intimacy and good feelings in the marriage. Low marital satisfaction can reduce motivation for sexual intimacy, or even supports sexual withdrawal and can cause low sexual desire, dissatisfaction and tension. Marital dissatisfaction of couples negatively affect development and maintenance of SD (53). This mutual cycle is thought to involve some couples into SD's increasing pattern. Clinically, sexual problems are sometimes the consequence and sometimes the cause of dysfunctional or dissatisfied/unsatisfactory relationships (26). Generally it is hard to determine which one is the first- not intimate or loveless relationship or sexual desire and/or performance problems causing spouse avoidance or antipathy etc. Although our findings show that couples with SD have low marital adjustments, it does not allow determining the causal relationship between SD and marital adjustment.

In recent years the studies on sexual satisfaction have been seen to be increasing (32). The studies have found relationship between SD such as erectile disorder, vaginismus and premature ejaculation, and sexual satisfaction $(35,59,23,15)$. Sánchez-Fuentes et al. (32) made a comprehensive review of literature on sexual satisfaction. According to the findings they obtained, many studies suggested that there is a relationship between sexual functioning and satisfaction. In these studies, it was seen that desire, arousal, orgasm consistency, frequency of sex and diversity of sexual behavior are related to higher sexual satisfaction, while lack of desire, vaginal dryness, erectile dysfunction, premature ejaculation, inability to reach orgasm and pain during sex are related to lower sexual satisfaction. In this review, the studies were concluded not to indicate a significant difference women and men in terms of sexual satisfaction levels (32). In our study, significant differences were found between the two groups for both women and men. It was observed that couples with SD had less sexual satisfaction than the couples in the comparison group. The existence of sexual problems seem to reduce couples' sexual satisfactions. This finding is compatible with the literature.

The study has several restrictions. The cross sectional of the study is a restriction. So as to find answers to the question of directionality, the studies to be conducted longitudinally in the future should be considered. This study is a hospital-based study and is a referral study from another unit. Referral bias may be possible in the selection of the study group. The major problem with this type of bias is that associations between risk factors and disease cannot accurately be calculated in an unrepresentative group taken from a larger population. The comparison group is a non-randomized (availability sample) sample. All of these restrict the generalizability of our findings. Therefore, the results should be carefully interpreted. An assessment was not made according to specific diagnosis groups in SD. Making assessments according to specific diagnosis groups in women and men will allow these variables to be examined in a more detailed way. Using self-report scales is another restriction. In the assessment of personality dimensions in clinical or nonclinical groups, future studies in which different methods (i.e. clinical interviews) are used should be considered. Other restriction was that DSM-IV-TR diagnostic criteria 
were used in this study because this study got started before DSM-5 was published.

Consequently, in couples with SD, certain personality traits (cyclothymic character in both genders, high harm avoidance temperament trait and low self-directedness character trait in women) may contribute the development and maintenance of sexual problems as a risk factor. Marital adjustment and sexual satisfaction are insufficient in couples with SD. Undoubtedly, these findings do not give us information about the cause-effect relationships. For this, it would be useful to examine the mentioned variable relations in a model framework. Besides, it is seen that very few studies were made with TCI in SD. Even though our findings are important, more studies need to be conducted with TCI and findings need to be repeated. Still, these findings have important implications for understanding sexual problems as well as the evaluation and treatment strategies of SD. In making evaluation, it is important to consider these features and include them in sexual therapy protocols. Cognitive-behavioral approach for reconstructing dysfunctional personality traits and behavior patterns, and interpersonal psychotherapy can be important therapeutic strategies. Considering that temperament traits do not change, it can give better results to incline to character traits. During sexual therapies, it is important to deal with the issues on the couples' relationships in terms of developing the efficiency of treatment (56). Also, although resolving the SD often results in decreased sexual dissatisfaction, it does not necessarily result in increased sexual satisfaction (60). It is important to consider sexual satisfaction together with SD in treatment.

Correspondence address: Assist. Prof.. Dr. Cennet Şafak Öztürk, Adnan Menderes University Faculty of Arts and Sciences, Department of Psychology, Aydın, Turkey cennet.ozturk@adu.edu.tr 


\section{REFERENCES}

1. American Psychiatric Association. Diagnostic and Statistical Manual Of Mental Disorders. 5th ed. Arlington, VA: American Psychiatric Association; 2013.

2. Amerikan Psikiyatri Birliği. DSM-IV-TR Tanı Ölçütleri Başvuru El Kitabı. Köroğlu E (Çeviri ed.). İkinci baskı (2005). Ankara: Hekimler Yayın Birliği; 2000.

3. Laumann EO, Paik A, Rosen RC. Sexual dysfunction in the United States: Prevalence and predictors. JAMA 1999; $281: 537$. 44.

4. Oksuz E, Malhan S. Prevalence and risk factors for female sexual dysfunction in Turkish women. J Urol 2006; 175: 654-658.

5. Oksuz E, Malhan S. The prevalence of male sexual dysfunction and potential risk factors in Turkish men: a web-based survey. Int J Impot Res 2005; 17: 539-545.

6. Bozkurt A, Ozmenler KN, Karlidere T, Işıklı H, Gulsun M, Ak M, Yetkin S, Ozgen F, Ozsahin A, Aydın H. Characteristics of male sexual dysfunction subjects from a sociocultural perspective: Analysis of 18 years. New/Yeni Symposium Journal 2013; 51: 37-45.

7. Sungur MZ. Erkek cinsel işlev bozuklukları. Psikiyatri Dünyası 1999; 3: 60-64.

8. Harris JM, Cherkas LF, Kato BS, Heiman JR, Spector TD. Normal variations in personality are associated with coital orgasmic infrequency in heterosexual women: A populationbased study. J Sex Med 2008; 5: 1177-1183.

9. McCabe M, Althof SE, Assalian P, Chevret-Measson M, Leiblum SR, Simonelli C, Wylie, K. Psychological and interpersonal dimensions of sexual function and dysfunction. J Sex Med 2010; 7: 327-336.

10. Andersen AM, Bienvenu OJ. Personality and psychopathology. Int Rev Psychiatry 2011; 23: 234-247.

11. Mullins-Sweatt SN, Lengel GJ. Clinical utility of the FiveFactor Model of personality. J Pers 2012; 80: 1615-1639.

12. Cloninger CR, Svrakic DM, Przybeck TR. A psychobiological model of temperament and character. Arch Gen Psychiatry 1993; 50: 975-990.

13. Conrad R, Schilling G, Bausch C, Nadstawek J, Wartenberg HC, Wegener I, Geiser F, Imbierowicz K, Liedtke R. Temperament and character personality profiles and personality disorders in chronic pain patients. Pain 2007; 133: 197-209.

14. Heaven PCL, Fitzpatrick J, Craig FL, Kelly P, Sebar G. Five personality factors and sex: Preliminary findings. Personality and Individual Differences 2000; 28: 1133-1141.

15. Konkan R, Bayrak M, Gönüllü OG, Şenormancı Ö, Sungur MZ. Vajinusmuslu kadınlarda cinsel işlev ve doyum. Düşünen Adam Psikiyatri ve Nörolojik Bilimler Dergisi 2012; 25: 305-311.

16. Leeners B, Hengartner MP, Ajdacic-Gross V, Rössler W, Angst J. Dyspareunia in the context of psychopathology, personality traits, and coping resources: Results from a prospective longitudinal cohort study from age 30 to 50. Arch Sex Behav 2015; 44: 1551-1560.

17. Rosenheim E, Neumann M. Personality characteristics of sexually dysfunctioning males and their wives. J Sex Res 1981;
17: $124-38$

18. Leeners B, Hengartner MP, Rössler W, Ajdacic-Gross V, Angst J. The role of psychopathological and personality covariates in orgasmic difficulties: A prospective longitudinal evaluation in a cohort of women from age 30 to 50. J Sex Med 2014; 11: 2928-2937.

19. Kennedy SH, Dickens SE, Eisfeld BS, Bagby RM. Sexual dysfunction before antidepressant therapy in major depression. J Affect Disord 1999; 56: 201-8.

20. Quinta Gomes AL, Nobre P. Personality traits and psychopathology on male sexual dysfunction: an empirical study. J Sex Med 2011; 8: 461-469.

21. Crisp C, Vaccaro C, Fellner A, Kleeman S, Pauls R. The influence of personality and coping on female sexual function: A population survey. J Sex Med 2015; 12: 109-115.

22. Peixoto MM, Nobre P. Personality traits, sexual problems, and sexual orientation: An empirical study. J Sex Marital Ther 2016; 42: 199-213.

23. Kempeneers P, Andrianne R, Bauwens S, Georis I, Pairoux JF, Blairy S. Functional and psychological characteristics of Belgian men with premature ejaculation and their partners. Arch Sex Behav 2013; 42: 51-66.

24. Spanier GB, Lewis RA. Marital quality: A review of the seventies. Journal of Marriage and The Family 1980; 42: 825-839.

25. Amidu N, Owiredu WKBA, Gyasi-Sarpong CK, Woode E, Quaye L. Sexual dysfunction among married couples living in Kumasi metropolis, Ghana. BMC Urology 2011; 11: 3.

26. Althof SE, Leiblum SR, Chevret-Measson M, Hartmann U, Levine SB, McCabe M, Plaut M, Rodrigues O, Wylie K. Psychological and interpersonal dimensions of sexual function and dysfunction. J Sex Med 2005; 2: 793-800.

27. McCarthy B. Marital sex as it ought to be. Journal of Family Psychotherapy 2003; 14: 1-12.

28. Trudel G, Boulos L, Matte B. Dyadic adjustment in couples with hypoactive sexual desire. Journal of Sex Education and Therapy 1993; 19: 31-36.

29. Trudel G, Landry L, Larose Y. Low sexual desire: The role of anxiety, depression and marital adjustment. Sexual and Marital Therapy 1997; 12: 95-99.

30. Gülsün M, Aydın H, Gülçat Z. Evlilik ilişkisi ve kadın cinsel işlev bozukluğu üzerine bir çalışma. Türkiye'de Psikiyatri 2006; 8: 67-73.

31. Davis HJ, Reissing ED. Relationship adjustment and dyadic interaction in couples with sexual pain disorders: a critical review of the literature. Sexual and Relationship Therapy 2007; 22: $245-254$.

32. Sánchez-Fuentes MM, Santos-Iglesias P, Sierra JC. A systematic review of sexual satisfaction. International Journal of Clinical and Health Psychology 2014; 14: 67-75.

33. Haavio-Mannila E, Kontula O. Corraletes of increased sexual satisfaction. Arch Sex Behav 1997; 26: 399-419.

34. Byers ES, MacNeil S. Further validation of the interperson- 
Temperament and character dimensions, marital adjustment, and sexual satisfaction in couples with sexual dysfunction

al exchance model of sexual satisfaction. J Sex Marital Ther 2006; 32: 53-69.

35. Çayan S, Bozlu M, Canpolat B, Akbay E. The assessment of sexual functioning in women with male partners complaining of erectile dysfunction: Does treatment of male sexual dysfunction improve female partner's sexual functions? J Sex Marital Ther 2004; 30: 333-341.

36. Derogatis LR, Meyer JK. The invested partner in sexual disorders: A profile. Am J Psychiatry 1979; 136: 1545-1549.

37. Köse S, Sayar K, Ak İ, Aydın N, Kalelioğlu Ü, Kırkpınar İ, Reeves RA, Przybeck TR, Cloninger CR. Mizaç ve Karakter Envanteri (Türkçe TCI): Geçerlik, güvenirliği ve faktör yapısı. Klinik Psikofarmakol Bülteni 2004; 14: 107-131.

38. Arkar H, Sorias O, Tunca Z, Şafak C, Alkın T, Binnur Akdede B, Şahin S, Akvardar Y, Sarı Ö, Özerdem A, Cimilli C. Mizaç ve Karakter Envanteri'nin Türkçe formunun faktör yapısı, geçerlik ve güvenilirliği. Turk Psikiyatri Derg 2005; 16:190-204.

39. Spanier GB. Measuring dyadic adjustment: New scales for assessing the quality of marriage and similar dyads. Journal of Marriage and Family 1976; 38: 15-28.

40. Fışıloğlu H, Demir A. Applicability of the Dyadic Adjustment Scale for marital quality with Turkish couples. European Journal of Psychological Assess 2000; 16: 214-218.

41. Rust J, Golombok S. The GRISS: A psychometric instrument for the assessment of sexual dysfunction. Arch Sex Behav 1986; 15: 157-165.

42. Tuğrul C, Öztan N, Kabakçı E. Golombok-Rust Cinsel Doyum Ölçeği'nin standardizasyon çalışması. Turk Psikiyatri Derg 1993; 4: 83-88.

43. Erdfelder E, Faul F, Buchner A. GPOWER: A general power analysis program. Behavior Research Methods, Instruments, \& Computers 1996; 28: 1-11.

44. Cohen J. Statistical Power Analysis for the Behavioral Sciences. Second ed. Hillsdale, NJ: Lawrence Erlbaum Associates, Inc; 1988.

45. Cloninger CR, Bayon C, Svrakic DM. Measurement of temperament and character in mood disorders: a model of fundamental states as personality types. J Affect Disord 1998; 51: 2132.

46. Crisp CC, Vaccaro CM, Pancholy A, Kleeman S, Fellner AN, Pauls R. Is female sexual dysfunction related to personality and coping? An exploratory study. Sex Med 2013; 1: 69-75.

47. Lundqvist EN, Bergdahl J. Vestibulodynia (former vulvar vestibulitis): Personality in affected women. J Psychosom Obstet Gynaecol 2005; 26: 251-256.

48. Danielsson I, Eisemann M, Sjöberg I, Wikman M. Vulvar vestibulitis: A multi-factorial condition. BJOG 2001; 108: 45661.

49. Nylanderlundqvist E, Bergdahl J. Vulvar vestibulitis: evidence of depression and state anxiety in patients and partners. Acta Derm Venereol 2002; 83: 369-373.

50. Granot M, Lavee Y. Psychological factors associated with perception of experimental pain in vulvar vestibulitis syndrome.
J Sex Marital Ther 2005; 31: 285-302.

51. Desrochers G, Bergeron S, Landry T, Jodoin M. Do psychosexual factors play a role in the etiology of provoked vestibulodynia? A critical review. J Sex Marital Ther 2008; 34: 198-226.

52. Borg C, Peters ML, Schultz WW, de Jong PJ. Vaginismus: heightened harm avoidance and pain catastrophizing cognitions. J Sex Med 2012; 9: 558-567.

53. Metz ME, Epstein N. Assessing the role of relationship conflict in sexual dysfunction. J Sex Marital Ther 2002; 28: 139-164.

54. Barnes GE, Malamuth NM. Eysenck's theory of personality and sexuality. Psihologija 1998; 3: 239-248.

55. Chiara G, Eva G, Elisa M, Luca R, Piera B. Psychometrical properties of the Dyadic Adjustment Scale for measurement of marital quality with Italian couples. Procedia - Social and Behavioral Sciences 2014; 127: 499-503.

56. McCabe MP. Relationship factors in the development and maintenance of ED: Implications for treatment effectiveness. J Sex Med 2008; 5: 1795-1804.

57. Gautam S, Batra L. Sexual behaviour and dysfunction in divorce seeking couples. Indian J Psychiatry 1996; 38: 109-116.

58. Boddi V, Fanni E, Castellini G, Fisher AD, Corona G, Maggi M. Conflicts within the family and within the couple as contextual factors in the determinism of male sexual dysfunction. J Sex Med 2015; 12: 2425-35.

59. Doğan S, Varol Saraçoğlu G. Yaşam boyu vajinismusu olan kadınlarda, cinsel bilgi, evlilik özellikleri, cinsel işlev ve doyumun değerlendirilmesi. Trakya Üniversitesi Tıp Fakültesi Dergisi 2009; 26: 151-158.

60. Byers ES. The interpersonal exchange model of sexual satisfaction: Implications for sex therapy with couples. Canadian Journal of Counselling 1999; 33: 95-111. 